\title{
The Relationship between Experience and Demographic Variables on Concern with Apparel Fit in Online Context
}

\author{
Moudi Almousa ${ }^{1}$ \\ ${ }^{1}$ Moudi Almousa, King Saud University, Saudi Arabia \\ Correspondence: Moudi Almousa, King Saud University, Saudi Arabia.
}

Received: October 16, 2019

Accepted: November 8, 2019

Online Published: November 14, 2019

doi:10.5539/ibr.v13n1p11

URL: https://doi.org/10.5539/ibr.v13n1p11

\begin{abstract}
Although apparel fit and size has been investigated in previous research, it is yet to be test to understand apparel consumer behavior in ecommerce and their concern with being unable to try on clothing or imagine fit/size before making purchase decision. Therefore, the purpose of this exploratory study was to examine the relationship between concern with inability to try on clothing and imagining size/fit in online context and their relationship with demographic variables and previous experience. While these study findings indicated no significant relationship between demographic variables and apparel online shopping orientation, other psychographic variable should be explored.
\end{abstract}

Keywords: consumer behavior, online shopping, experience, apparel fit/size

\section{Introduction}

During the past few decades the importance of the Internet as a shopping channel has increased rapidly as Internet penetration and adoption levels increased among consumers (Ha and Stoel 2009; Colton, Roth, and Bearden 2010). Internet access has grown rapidly from $4 \%$ to $40 \%$ among world's population during the past two decades, and developing economies are rapidly adopting digital technologies in different areas from banking to agriculture and e-commerce (OECD, 2017). Digital consumption in developing countries is growing rapidly where one of the biggest driving forces is the increasing consumer demand to for e-commerce (BCG, 2018). According to BCG analysis of forecasts from Forrester Research and from eMarketer, more than 2.2 billion consumers are projected online in emerging markets, where 550 million of them made at least one online purchase in 2016.

Saudi Arabia is a developing country and one of the G-20 economies ranked 33ed in the Network Readiness Index and Internet user penetration is 64.4\% (Statistica, 2018). It has the largest retail market in the Middle East representing approximately 17 percent of the country's GDP. It is one of the immense industries across the Gulf Cooperation Council GCC region, where it holds 70 percent with value exceeded $\$ 170$ billion and an annual growth rate of 12 per cent (Jadwa Investment, 2017). According to Statistica (2018), the e-commerce market revenue amounts to over $\$ 6$ billion and the share for fashion products amounts to nearly $\$ 2$ billion where it is the second largest segment after consumer electronics with annual growth rate of 30 percent during the past five years (Al-Kibsi, et, al., 2015). One of the biggest drivers for the rapid increase in Internet penetration rates and e-commerce growth is the unique demographic structure of the country, where 65 percent of the population is under the age of 35 (Saudi General Authority for Statistics, 2016), which represents a tech-savvy generations. Although consumers have concerns while shopping online, apparel shoppers in particular might feel more concerned since apparel has to fit the different body size and shape for each consumer. In addition, the country has no standard sizing for apparel and very limited apparel manufacturing, which makes most purchases across borders, adding more time and financial risk to online apparel purchasers. Despite Saudi Arabia's retail market significance, the e-commerce growth potential, and the unique demographic structure, examinations of its online apparel consumers, especially concern with inability to try on garments before purchase has not been examined. The purpose of this exploratory study is to investigate Saudi female online apparel consumers' concern with inability to try on clothing and their concern with imagining size/fit in online context and their relationship with demographic variables and previous experience.

\section{Literature Review}

The concept of apparel fit has been investigated in past apparel research as it is considered a central component 
of consumer satisfaction and apparel quality (Song \& Ashdown, 2010). Brown and Rice (2001) defined apparel fit as "how well the garment conforms to the three-dimensional human body" (p. 153). Consumers view fit and size as one of the most important evaluation criteria when purchasing clothing from retail store (Hsu \& Burns, 2002; Eckman, Damhorst, \& Kadolph, 1990), as it is directly related to both the tactile elements, which is related to the level of comfort of the wearer and the visual element which is related to how the wearer is viewed by the public (Forst, 1988). Pervious research indicated that consumers are having problems with apparel fit and sizing as manufacturers and retailers are using different sizing charts (Clifford, 2011) causing consumers to spend more time in retail stores' fitting rooms and possibly causing frustration. Such issue might be more serious in countries with no previous sizing surveys and no standard sizing system for the population such as Saudi Arabia. No previous literature has been found investigating Saudi female consumers' satisfaction regarding ready-to-wear apparel.

\subsection{Concern with Apparel Fit in Online Context}

During shopping online for apparel consumers may experience more difficulty regarding fit and size because of their inability to try on clothing before purchase. What makes the situation even more difficult is that clothing fit is determined not only by fit but other elements related to posture, and complex body proportions (Song \& Ashdown, 2010). While shopping in a brick and mortar stores, consumers can physically try on garments and make visual and alive evaluation through examining the body-related information (Rosa, Garbarino \& Malter, 2003). While shopping for clothing in online environments, consumers may rely on their imagination to picture the garment on their bodies. Since most apparel e-tailors use models with ideal body, consumers may attempt to visualize themselves wearing the garment they view in the website to evaluate if the garment would conform to their body shape and size. This imagination process may cause emotional distress to consumers by comparing their bodies to the ideal body of the model, which may result in self-discrepancy. Self-discrepancy theory delineates that individuals compare themselves to internalized values or "self-guides" where the self-discrepancy or the gap between the two results in emotional discomfort (Orellana-Damacela, et al., 2000).

Apparel is considered a high body-involving product where its usage experience is closely associated with fit and tactile information such as feel and touch (Rosa et al., 2003). Pastore, 2000; Rosa et al., (2003) argue that, while shopping online for apparel consumers make purchase decision by relying on their imagination, which may increase their risk. Previous research has identified three dimensions of perceived risk including time, financial, and product risk while shopping online for apparel related to inability to try on and touch the product before making the purchase (Forsythe et al., 2006). Almousa (2011) examined the influence of risk from a multidimensional perspective on intention to purchase apparel online and found that time and performance risks have the most significant influence.

Despite the popularity of apparel products in online context, it is faced with a major logistic challenge of high volume returns estimated around $40-50$ percent of total online sales (Forbes, 2016). The differences in the sizing systems used by apparel retailers contributed to $\$ 194$ billion of retunes for apparel purchased online (National Retail Federation, 2010). Many startup technology companies are trying to provide B-B or B-C solutions to enable consumers to virtually try on or use sophisticated algorithms to predict the appropriate size for online consumer before purchasing apparel. Despite the importance of such issue for both online apparel retailers and consumers, previous researchers have not clearly identified consumers' concern with inability to try on garments before purchasing in online contexts. Few studies have investigated the subject from perspectives of developed countries' consumers where ecommerce infrastructure is established and e-retailers might be within border, which may reduce perceived risk. Since Internet transformed the world as a global village, international marketing researchers have stressed the significance of knowing what influence forging consumers and how they behave in online environments (Singh et al., 2006 and Colton et al., 2010). No research has been found examining consumers' concern with inability to try on garments in online contexts from developing countries. In this context, the current study attempts to fill the gap in this research area.

Previous research has indicated the importance of socio-demographic variables (Choudrie and Dwivedi, 2005; So, Wong and Sculli, 2005; Venkatesh et al., 2003; and Venkatesh and Zhang 2010) and level of experience (Venkatesh and Zhang 2010) in explaining consumer behavior in e-commerce. The diffusion of innovation theory (Rogers, 2003), proposed that socio-demographic variables play an important role in predicting technology adopters. Madden and Savage (2000) found that Internet early adapters in Australia were educated young males with high income. Almousa (2011) found age to be a significant predictor of using the Internet as a shopping channel, where young consumers; both male and female, adopt e-commerce more than older age groups. No previous studies were found that examined the relationship between socio-demographic variables and consumers' concern with inability to try on clothing in online environments. Through mirroring the evidence in 
previous research regarding the relationship between consumer behavior towards Internet use and adoption as a shopping channel and the socio-demographic variables, this research paper hypothesis that:

H1: There will be a statistically significant relationship between demographic variables (age, education, occupation, and income) and a) concern with inability to try on apparel products in online environments, and b) concern with imagining fit/size in online shopping.

Experience can positively affects customers' intention to purchase online Zhou et al. (2007), where consumers with higher experience have more satisfaction with online shopping resulted in increased number of completed purchases. While Dholakia and Zhao (2010) argue that experienced customers are difficult to satisfy, because of obtained accumulated information. Previous research had investigated the direct or moderating effect of experience on different contexts of using the Internet such as intention to shop online (Hsieh and Liao, 2011; Khalifa and Liu 2007), perception towards online shopping Saprikis et al. (2010), and online banking (Dagger and O'Brien, 2010). Though, the influence of experience on inability to try on garments in online contexts has not been examined. Given this backdrop, this research hypothesis that:

H2: There will be a statistically significant relationship between online apparel shopping experience and concern with a) inability to try on apparel products in online environments, and b) concern with imagining fit/size in online shopping.

\section{Methodology}

The targeted sample for this study is young Saudi women. Apparel was chosen in this study as it is the second largest market segment in Saudi e-commerce in 2017. According to Statistica (2017), 64.2 percent of apparel online buyers are 18-34 years old and the number is expected to amount to $20.2 \mathrm{~m}$ by 2023 . Moreover, this young age group is tech savvy and familiar with using the Internet as a shopping channel (Seock and Norton, 2007b) and more involved with apparel products (Kim, Damhorst, Lee, 2002). A web-based survey was used to collect data for this study, where recruitment e-mail sent via electronic services to female students and staff in a large university in Riyadh, Saudi Arabia. The email includes an invitation to participate in the study with at least one online apparel purchase during the last six months as inclusion criteria, as well as a link to the survey. Before sending e-mail invitation, the questionnaire was pretested with 15 students to test for clarity and validity.

\subsection{Sample}

Data was collected during the month of May 2018, and 288 responses were collected. Four responses were eliminated due to not making any apparel online purchase during the six months prior to data collection. The majority of respondents' ages ranged between 18 -28 years $(82.9 \%)$ while $(17.1 \%)$ ranged between $28-37$ years. They were mainly single (87.8\%) students (85.4\%), and have bachelor degree (63.4\%), high school (22\%), and graduate degree (14.6\%). Forty-tow percent of respondent monthly household incomes were in the middle-income category ranging between 10,001 - 20,000 Saudi riyals, $(20.7 \%)$ in the low income category ranging between $5,000-10,000,(20.6 \%)$ in the upper middle ranging from $20,001-30,000$, and $(15.9 \%)$ were in the high income category of over 30,000 Saudi riyals.

\subsection{Measures}

The questionnaire consisted of four parts, where the first part includes demographic information including (age, level of education, marital status, employment status, and household monthly income), and the second includes apparel online shopping orientation. The next part includes five attributes measuring consumers' concern with inability to try on clothing when shopping online, while the last part encompasses three attributes measuring consumers' concern with imagining fit/size when shopping online for clothing. These two scales were adopted from Kim and Damhorst (2013) using a seven-point Likert scale where $(1=$ strongly disagree and $7=$ strongly agree). The Apparel online shopping experience, was operationalize by number of purchases that customer made during the past six months prior to data collection and years of experience shopping online. Table 1 illustrates measurement items, descriptive statistics, and reported reliabilities.

Regarding respondents' apparel online shopping orientation, (39.1\%) spent between $500-1000$ S.R. on apparel products bought through the Internet during the six moths period prior to data collection. It appears that the majority of respondents purchased apparel online between 1-2 times (36.23\%) and 3 - 4 times (37.68\%) during the same period. More than fifty six percent of respondents have $1-3$ year of experience of shopping for apparel products online, followed by (30.45\%) have more than three yeas of experience (see Table 2 ). 
Table 1. Descriptive statistics of study measurements and reported reliabilities

\begin{tabular}{|c|c|c|c|c|c|c|c|c|c|c|}
\hline Dimension & 1 & 2 & 3 & 4 & 5 & 6 & 7 & Mean & SD & Alpha Value \\
\hline \multicolumn{8}{|c|}{ Concern with inability to try on in shopping online for apparel } & $\mathbf{1 . 9 3 3 3}$ & .69423 & \multirow{6}{*}{.812} \\
\hline $\begin{array}{l}\text { The fit of the garment may be } \\
\text { different from what I see on the } \\
\text { website }\end{array}$ & & 2.9 & 2.9 & 5.8 & 21.7 & 39.1 & 27.5 & 5.74 & 1.184 & \\
\hline $\begin{array}{l}\text { The garment on the website may } \\
\text { look different when I try it on at } \\
\text { home }\end{array}$ & & & & 7.2 & 17.3 & 49.2 & 26.1 & 5.94 & .856 & \\
\hline $\begin{array}{l}\text { The garment may fit differently on } \\
\text { me that it fits on the model }\end{array}$ & & & 2.9 & 1.5 & 17.3 & 42 & 36.2 & 6.07 & .929 & \\
\hline $\begin{array}{l}\text { Depending on the brand, the garment } \\
\text { fit may be different }\end{array}$ & & & 1.5 & & 10.14 & 36.2 & 52.1 & 6.38 & .788 & \\
\hline $\begin{array}{l}\text { The garment may not fit all body } \\
\text { shapes and sizes }\end{array}$ & & & & 2.9 & 13 & 44.9 & 39.13 & 6.20 & .778 & \\
\hline \multicolumn{8}{|c|}{ Concern with imagining fit/size in online shopping } & 5.0000 & 1.2880 & \multirow{4}{*}{.848} \\
\hline $\begin{array}{l}\text { Shopping in the website, I may have } \\
\text { a hard time picturing myself wearing } \\
\text { the garment }\end{array}$ & 2.9 & 7.2 & 4.3 & 15.9 & 33.3 & 21.7 & 14.5 & 4.928 & 1.508 & \\
\hline $\begin{array}{l}\text { I may have a hard time imagining } \\
\text { the fit of the garment shopping in the } \\
\text { website }\end{array}$ & 2.9 & 5.8 & 10.1 & 15.9 & 23.2 & 27.5 & 14.5 & 4.913 & 1.560 & \\
\hline $\begin{array}{l}\text { My guess about the garment fit may } \\
\text { not be correct when shopping in the } \\
\text { website }\end{array}$ & 1.4 & 2.9 & 8.7 & 10.1 & 31.9 & 31.9 & 13.0 & 5.159 & 1.335 & \\
\hline
\end{tabular}

Table 2. Percentage distribution of respondent's shopping orientation

\begin{tabular}{lll}
\hline Online shopping orientation & Item & Distribution \\
\hline Approximately, how much did you spend on & $<500$ S.R. & $18.8 \%$ \\
apparel bought online during the last six months & $500-1000$ S.R. & $11.6 \%$ \\
& $1001-1500$ S.R. & $10.1 \%$ \\
\cline { 2 - 3 } & $1501-2000$ S.R. & $20.3 \%$ \\
\cline { 2 - 3 } Approximately, how many times did you purchase & $>2000$ S.R. & $36.23 \%$ \\
apparel bought online & $3-4$ times & $37.68 \%$ \\
& More than 4 times & $18 \%$ \\
\hline How long have you been using the internet to buy & Less than a year & $13 \%$ \\
apparel online & $1-3$ years & $56.5 \%$ \\
& More than 3 years & $30.45 \%$ \\
\hline
\end{tabular}

\section{Results}

Correlation analysis was conduct to test research hypothesis wither there are relationship between consumers' demographics and previous experience on shopping online for apparel and their concern with inability to try on apparel product and imagining how they fit on the body when purchasing in ecommerce context. Although correlation coefficients for demographic variables were positively and negatively correlated with each other, results revealed that there were no significant correlation between respondents' inability to try on apparel product in online context and the five demographic variables of marital status, age, educational level, employment status, and monthly income $(\mathrm{r}=-.004, .015, .137, .031$, and .185) respectively, and difficulty in imagining fit on the body $(\mathrm{r}=-.120, .080, .071, .000$, and -.130$)$ for the five demographic variables respectively, therefore H1a and $\mathrm{H} 1 \mathrm{~b}$ were not supported. Table 3 demonstrates the Pearson correlation matrix for the tested variables.

To test the second hypothesis, correlation analysis was performed and indicated that no significant correlation between consumers' previous experience on shopping online for apparel and their concern with inability to try on apparel products $(r=.086, .086$, and .016$)$ for amount spent, number of purchases, and length of experience respectively. Correlation coefficients for imagining how they fit on the body when purchasing in ecommerce context ( $\mathrm{r}=.011,-.010$, and -.137$)$ for amount spent, number of purchases, and length of experience respectively. Therefore, H2a and $\mathrm{H} 2 \mathrm{~b}$ were not supported (Table 4). 
Table 3. Correlation Matrix of demographic variables and Study Constructs $(\mathrm{n}=284)$

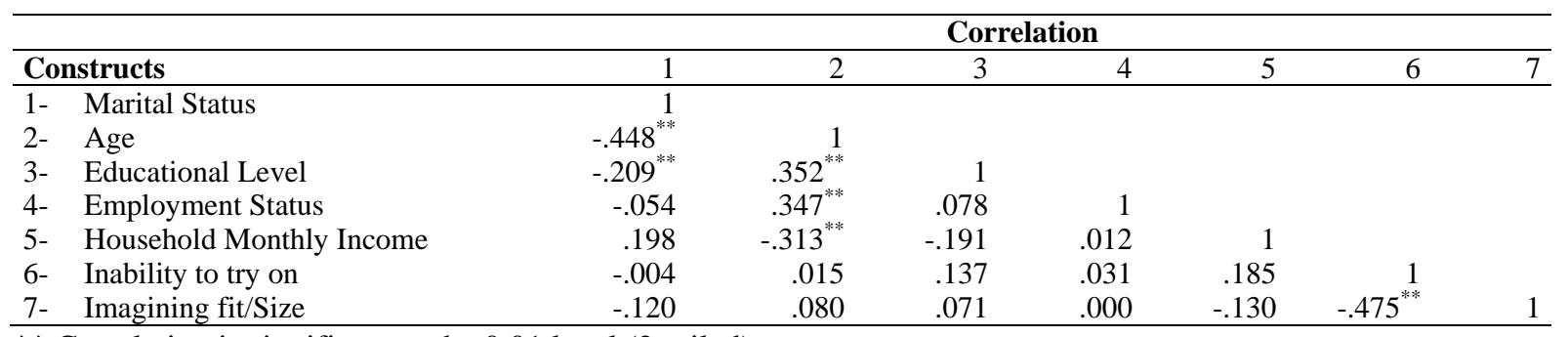

** Correlation is significant at the 0.01 level (2-tailed).

* Correlation is significant at the 0.05 level (2-tailed).

Table 4. Correlation Matrix of experience and Study Constructs $(n=284)$

\begin{tabular}{|c|c|c|c|c|c|}
\hline & \multicolumn{5}{|c|}{ Correlation } \\
\hline Constructs & 1 & 2 & 3 & 4 & 5 \\
\hline 1- Inability to try on & 1 & & & & \\
\hline 2- Imagining fit/size & $-.475^{* *}$ & 1 & & & \\
\hline 3- Amount spent on apparel online purchases & .086 & .011 & 1 & & \\
\hline 4- Number of purchases & .068 & -.010 & $.580^{* *}$ & 1 & \\
\hline 5- Years of experience & .126 & -.137 & $.357^{* *}$ & $.239^{*}$ & 1 \\
\hline
\end{tabular}

\section{Discussion}

This cross-sectional exploratory study attempted to investigate the relationship between apparel online shoppers' demographic variables and previous experience and their concern with inability to try on apparel product and imagining how they fit on the body when purchasing in ecommerce context. Results for this study showed no significant correlation between demographic variables and consumers level of concern being unable to try on clothing and imagining fit on the body when purchasing apparel online. Although demographic variables were found to be good predictors and correlated with consumer behavior in ecommerce (Venkatesh et al., 2003 and Choudrie and Lee, 2004), it is yet to be tested specifically with regard to this study variables.

A surprising finding was that experience in shopping online for apparel products has no significant correlation with consumers' concerns about not being able to try on or imagine fit/size when purchasing clothing online. It appears that experienced online apparel shoppers perceive similar concerns as other shoppers with less experience. This finding is consistent with Kim and Damhorst (2013) that these two dimensions were correlated with inability to try on products online. This might be attributed to that both designers and manufacturers do not apply standard sizing measurements. In addition to size, fit is evaluated through different attributes including posture, fabric drape, and complex body proportions (Song and Ashdown, 2010). It suggests that the information provided by retailers weather it is written, pictures, or videos, were not enough in reducing consumers' concerns. In order to reduce consumers' concerns, online retailers should include more information regarding size and fit such as sizing charts ease, and fit type in addition to fabric components and drape. Other solution for reducing consumers' concerns for not being able to try on clothing before purchase is collaborating with any technological startup that provides a platform to predict or recommend size for their customers after providing some demographic and measurement information. Such platforms work as enablers for reducing concern regarding size and fit for consumers as well as lowering return rate for online retailers. Despite the importance of apparel size and fit in online shopping channel, limited research has investigated this issue which is directly related to the major logistic challenge to apparel online retailer. More research is needed to understand possible applications or practices that can reduce consumers' risk as well as to reduce apparel returns. Moreover, future research should investigate other possible variables associated with concern with inability to try on or imagine fit/size when shopping for apparel online and to replicate this study to validate findings.

\section{References}

Al-Kibsi, G., Woetzel, J., Isherwood, T., Khan, J., Mischke, J., \& Noura, H. (2015). Saudi Arabia beyond oil: the investment and productivity transformation. Retrieved March 39, 2019, from http://www.mckinsey.com

Almousa, M., (2011). Perceived Risk in Apparel online Shopping: A multi Dimensional perspective. Canadian Social Science, 7(2).

BCG. (2018). Digital consumers, Emerging markets, and the $\$ 4$ trillion future. Retrieved from 
http://image-src.bcg.com/Images/BCG-Digital-Consumers-Emerging-Markets-and-the-\%244-Trillion-Futur e-Sep-2018_tcm9-202652.pdf

Brown, P., \& Rice, J. (2001). Ready-to-wear apparel analysis. Upper Saddle River, NJ: Prentice Hall.

Choudrie, J., \& Dwivedi, Y. K. (2005). The demographics of broadband residential consumers of a British local community: the London borough of Hillingdon. Journal of Computer Information Systems, 45(4), 93-101. https://doi.org/10.1080/08874417.2005.11645860

Clifford, S., (2011). One size fits no body: Seeking a steady 4 or 10. The New York Times, p. 1.

Colton, D. A., Roth, M. S., \& Bearden, W. O. (2010). Drivers of international e-tail performance: the complexities of orientations and resources. Journal of International Marketing, 18(1), 1-22. https://doi.org/10.1509/jimk.18.1.1

Dagger, T. S., \& O’Brien, T. K. (2010). Does experience matter? Differences in relationship benefits, satisfaction, trust, commitment and loyalty for novice and experienced service users. European Journal of Marketing, 44(9/10), 1528-1552. https://doi.org/10.1108/03090561011062952

Dholakia, R., \& Zhao, M. (2010). Effects of online store attributes on customer satisfaction and repurchase intentions. International Journal of Retail \& Distribution Management, 38(7), 482-496. https://doi.org/10.1108/09590551011052098

Eckman, M., Damhorst, M. L., \& Kadolph, S. J. (1990). Toward a model of the in-store purchase decision process: Consumer use of criteria for evaluating women's apparel. Clothing and Textiles Research Journal, 8(2), 13-22. https://doi.org/10.1177/0887302X9000800202

Forbes. (2016). Saudi Arabia. Retrieved from http://www.forbes.com/places/saudi-arabia

Forsythe, S., Liu, C., Shannon, D., \& Gardner, L. C. (2006). Development of a scale to measure the perceived benefits and risk of online shopping. Journal of Interactive Marketing, 20(2), 55-75. https://doi.org/10.1002/dir.20061

Frost, K. (1988). Consumer's perception of fit and comfort of pants (Unpublished master's thesis). University of Minnesota, St. Paul.

Hsieh, J. Y., \& Liao, P. W. (2011). Antecedents and moderators of online shopping behavior in undergraduate students. Soc. Behav. Pers, 39(9), 1271-1280. https://doi.org/10.2224/sbp.2011.39.9.1271

Hsu, H. J., \& Burns, L. D. (2002). Clothing evaluative criteria: a cross-national comparison of Taiwanese and United States consumers. Clothing and Textiles Research Journal, 20(4), 246-252. https://doi.org/10.1177/0887302X0202000408

Hye-Shin, K., Mary, L., \& Damhorst, K. L. (2002). Apparel involvement and advertisement processing: A model. Journal of Fashion Marketing and Management: An International Journal, 6(3), 277-302. https://doi.org/10.1108/13612020210441364

INSEAD, Global Information Technology Report (2016). Retrieved from http://www3.weforum.org/docs/GITR2016/WEF_GITR_Full_Report.pdf

Jadwa Investments Annual Report. (2017). Retrieved from http://www.jadwa.com/en/reportssection/about-jadwa/annual-reports/report-2017

Khalifa, M., \& Liu, V. (2007). Online consumer retention: contingent effects of online shopping habit and online shopping experience. European Journal of Information Systems, 16, 780-792. https://doi.org/10.1057/palgrave.ejis.3000711

Kim, H., \& Damhorst, M. (2013). Gauging concerns with fit and size among young consumers in online shopping. Journal of Textile and Apparel Technology and Management, 8(3), 1-14. Retrieved from https://ojs.cnr.ncsu.edu/index.php/JTATM/article/view/4566/2538

Madden, O., \& Savage, S. J. (2000). Some economic and social aspects of residential Internet use in Australia. The Journal of Media Economics, 13(3), 171-185. https://doi.org/10.1207/S15327736ME1303_2

National Retail Federation. (2010). State of Retailing Online Report. Retrieved from https://nrf.com/resources/state-retailing-online

OECD Digital Economy Outlook. (2017). OECD Publishing, Paris.

Orellana-Damacela, L. E., Tindale, T. S., \& Suarez-Balcazar, Y. (2000). Decisional and behavioral procrastination: 
How they relate to self-discrepancies. Journal of Social Behavior and Personality, 15, 225-238. Retrieved from https://ecommons.luc.edu/cgi/viewcontent.cgi?article=1026\&context=psychology_facpubs

Pastore M. (2000). Online Grocery Market Treading New E-Commerce Waters. Retrieved from http://cyberatlas.internet.com/markets/retailing/article/0,1323,6061_363871,00.html

Rogers, E. M. (2003). Diffusion of innovations. New York; London: Free Press.

Rosa, J. A., Garbarino, E. C., \& Malter, A. J. (2003). Keeping the body in mind: The influence of body esteem and body boundary aberration on consumer beliefs and purchase intentions. Journal of Consumer Psychology, 16(1), 79-91. https://doi.org/10.1207/s15327663jcp1601_10

Saprikis, V., Chouliara, A., \& Vlachopoulou, M. (2010). Perceptions Towards Online Shopping: Analyzing the Greek University Students' Attitude. Communications of the IBIMA, 2010, Article ID 854516. Retrieved from https://ibimapublishing.com/articles/CIBIMA/2010/854516/854516.pdf

Saudi General Authority for Statistics. (2016). Demographic statistics (Data file). Retrieved from https://www.stats.gov.sa/sites/default/files/en-demographic-research-2016_4.pdf

Seock, Y. K., \& Norton, M. (2007). Capturing college students on the web: analysis of clothing web site attributes. Journal of Fashion Marketing and Management, 11(4), 539-552. https://doi.org/10.1108/13612020710824599

Singh, N., Georg, F., Mike, C. H. C., \& Jonas, A. H. (2006). Understanding International Web Site Usage: A Cross-National Study of German, Brazilian, and Taiwanese Online Consumers. International Marketing Review, 23(1), 83-97. https://doi.org/10.1108/02651330610646304

So, W. C. M., Wong, T. N. D., \& Sculli, D. (2005). Factors Affecting Intentions to Purchase via the Internet. Industrial Management \& Data Systems, 105, 1225-1244. https://doi.org/10.1108/02635570510633275

Song, H. K., \& Ashdown, S. P. (2010). An exploratory study of the validity of visual fit assessment from three-dimensional scans. Clothing and Textiles Research Journal, 28(4), 263-278. https://doi.org/10.1177/0887302X10376411

Statistica. (2018). Retail e-commerce sales in the United States from 2017 to 2023. Retrieved from https://www.statista.com/statistics/272391/us-retail-e-commerce-sales-forecast/

Venkatesh, V., \& Zhang, X. (2010). Unified Theory of Acceptance and Use of Technology: U.S. Vs. China. Journal of Global Information Technology Management, 13(1). https://doi.org/10.1080/1097198X.2010.10856507

Venkatesh, V., Morris, M. G., Davis, G. B., \& Davis, F. D. (2003). User acceptance of information technology toward a unified view. MIS Quarterly, 27(3), 425-478. https://doi.org/10.2307/30036540

Zhou, L., Dai, L., \& Zhang, D. (2007). Online shopping acceptance model - a critical survey of -consumer factors in online shopping. Journal of Electronic Commerce Research, 8(1), 44-62. Retrieved from http://www.jecr.org/sites/default/files/08_1_p04.pdf

\section{Copyrights}

Copyright for this article is retained by the author(s), with first publication rights granted to the journal.

This is an open-access article distributed under the terms and conditions of the Creative Commons Attribution license (http://creativecommons.org/licenses/by/4.0/). 